\title{
A HISTORY OF THE REFORMATIONAL MOVEMENT IN BRITAIN. II: THE POST-WORLD-WAR II YEARS TO THE END OF THE TWENTIETH CENTURY
}

Author:

Steve Bishop ${ }^{1}$

\section{Affiliation:}

${ }^{1}$ City of Bristol College,

Bristol, United Kingdom

\section{Correspondence to:}

Steve Bishop

Postal Address:

100 North Road, Stoke

Gifford, Bristol BS34 8PE,

United Kingdom

Email:

stevebishop.uk@gmail.com

Dates:

15 August 2016

How to cite this article: Bishop, S., 2016. "A History of the Reformational

Movement in Britain. II: The Post-World-War II Years to the end of the Twentieth Century". KOERS - Bulletin for Christian Scholarship, 81(1). Available at: http:// dx.doi.org/10.19108/ KOERS.81.1.2251

\section{Copyright:}

(c) 2015. The Author(s).

Published under the

Creative Commons

Atribution License.
This paper looks at the development of neo-Calvinism in Britain during the period after World War II (WWII). Though the term neo-Calvinism is broad, the focus here will be on the Reformational strand associated with the approach of Kuyper, Dooyeweerd and Vollenhoven.

Keywords: neo-Calvinism, Reformational philosophy, Dooyeweerd, IARFA, Christian Studies Unit, WYSOCS, Britain

Hierdie artikel kyk na die ontwikkeling van neo-Calvinisme in Brittanje gedurende die tydperk ná die Tweede Wêreldoorlog. Alhoewel die term neo-Calvinisme breed is, is die fokus hier op die Reformatoriese Strand wat saamhang met die benadering van Kuyper, Dooyeweerd en Vollenhoven.

Sleutelwoorde: neo-Calvinisme, Reformatories filosofie, Dooyeweerd, IARFA, Christian Studies Unit, WYSOCS, Brittanje 


\section{INTRODUCTION}

The onset of WWII put on hold any international Calvinistic efforts and the development of the Reformational movement in Britain. After the war there were still turbulent years. Almost one million homes had been destroyed by the bombing raids. Winston Churchill warned that Britain would be almost certainly on the verge of being bankrupt. Food and fuel were in short supply and rationing was still being enforced. For many, things were worse after the war than before it. The period postWWII prior to the 1950 s has been characterised as an 'age of austerity' (Brown 2009:170) However, in the 1950s there was economic growth and the rise of a welfare state meant that many were able to escape from dire poverty. Britain opened up its doors to migrant workers from the former colonies to help with the labour shortage. Immigration helped Britain out of austerity (a lesson that seems to be forgotten today!). This meant the British were becoming more open to ideas that weren't just home-grown. In the same way it was international developments in the Reformational movement that were to have an effect on Britain.

Dooyeweerd did a lecture tour of the States in 1958, where he delivered the lectures that make up In the Twilight of Western Thought (Dooyeweerd, 1960; see Otto, 2005). The impact of his visit in the States led to an interest in his ideas there, but unfortunately he never lectured in Britain, though in 1947 the Evangelical Quarterly (EQ) published a paper by Dooyeweerd (Dooyeweerd, 1947). This was a lecture delivered to French students in Amsterdam and then translated into English for the journal. A similar article by Dooyeweerd was subsequently published in French in Mélanges Philosophiques (Dooyeweerd, 1948a). In the EQ paper Dooyeweerd framed his argument around three questions:

1. By what characteristics can scientific thought be distinguished from pre-scientific thought and common experience?

2. From what is abstraction made in scientific thought and how is this abstraction possible?

3. From what starting point is it possible to apprehend integrally, in a synthetic view the diverse aspects of reality which are analysed and opposed to one another in the antithetic relation?

The paper was also the foundation of Transcendental Problems of Philosophic Thought (Dooyeweerd, 1948b) written by Dooyeweerd in English. It was published in the United States but seemed to have had very little impact in Britain, at least as far as reviews in the journals are concerned. There was one in EQ by J.H.S. Burleigh but it merely notes that it is an expansion of an EQ article (The Editor, 1949) and one by R.J. Hirst (1949) in Mind. The lack of impact of the book was not indicative of the quality of the work but rather the availability of it as it was published by a North-American publisher. When Dooyeweerd died in 1977 there were no obituaries in British magazines or journals.
All was not lost, however, as attempts were made to resume the International Calvinistic Conferences. In 1948 one was held in Amsterdam on 'Calvin and the Modern Mind' and in 1953 in Montpellier with the theme 'The secularisation of modern life: The Reformed answer', where Dooyeweerd delivered his paper 'The secularization of science' (Dooyeweerd, 1954, 1966). It was out of the 1953 Montpelier conference that the International Association for Reformed Faith and Action (IARFA) was formed.

\section{IARFA}

IARFA came about largely due to the efforts of Jan Dengerink, Jacob Hoogstra and Pierre Marcel. The neo-Calvinist Dooyeweerdian influence was very much in evidence. Dengerink held the post of Secretary to the "Curatorium" or Board of Trustees of the Free University ${ }^{1}$ - he was later professor of Reformed Philosophy at the Universities of Utrecht and Groningen; Hoogstra had organised the first American Calvinistic Conference in the States (Hoogstra, 1939), ${ }^{2}$ and was involved with the US's Calvinistic Action Committee; the Frenchman Marcel (1910-1992) was influenced by August Lecerf and wrote two books on Dooyeweerd's philosophy - these have been recently translated into English by Colin Wright (Marcel, 2013a,b).

Jan Dengerink's address to the IFES (International Fellowship of Evangelical Students) in 1954 was published in the British magazine of the Inter-Varsity Fellowship: Christian Graduate. In closing he states:

Ought our evangelistic and our cultural work to be separated so easily? It is my profound conviction the answer must be 'No!' The two are closely interwoven in existence. But in any case both must submit to the coming of the one and indivisible kingdom of God in Jesus Christ.' (Dengerink, 1954). ${ }^{3}$

The IARFA published the International Reformed Bulletin (IRB), and the first issue was published in April 1958. In an IRB editorial, Jan Dengerink described the IARFA as 'not an ecclesiastical organization. It is not subject to the authority

$\overline{1}$ In this position he had unrivalled opportunities to meet, entertain, mentor and develop friendships with numerous overseas students who came to Amsterdam to do postgraduate study in various faculties (David Hanson, personal communication, 18/02/2016).

2 The only person in the attendance list from Britain was John Macleod who delivered two addresses. The Scot John Murray was also there but at the time was at Westminster Theological Seminary.

3 In the same issue one of the influential British Calvinstic Evangelicals, Jim Packer, reviewed The Christian Approach to Culture by Emile Caillet. In it he mentions Kuyper:

'As Kuyper and Chesterton, from opposite sides of the fence, used to insist, there are only two world-views that may be called Christian: the Catholic and the Calvinist. To turn one's back on the world and its culture is not Christian, but a hangover from the Manichean heresy: a denial of the goodness of the created order' (Packer, 1954:7). 
of church bodies. It wants to be a society of private persons of reformed confession' (Dengerink, 1962b:1). The editor was British-based Philip Edgcumbe Hughes (1915-1990). Hughes was born in Australia, grew up in South Africa and lived in the UK from his ordination training period until he moved to the USA in 1964.

He taught at Tyndale Hall (1947-1953), later to merge with other colleges to form Trinity College, Bristol. He was for a time secretary of the Church Society and edited its journal The Churchman from 1959-1967 (Beckwith, 1990). He was editor of Creative Minds in Contemporary Theology, which contained a chapter on Dooyeweerd (Young, 1966). In his introduction Hughes writes:

Of particular significance is the development by Herman Dooyeweerd of a system of Christian philosophy - a work of immense erudition constructed in loyalty to the principles of the biblical revelation which are also the principles of Reformed thought. (Dooyeweerd will frown at finding himself placed among the theologians in this volume; but his philosophy is erected upon a genuinely theological foundation.) (Hughes, 1966:24)

Three Reformational scholars contributed chapters, viz. Robert Knudsen, Paul Schrotenboer and J.J. Duyvené de Wit. Hughes also contributed to the 1965 Festschrift for Dooyeweerd (De Gaay Fortman et al., 1965).

Dengerink took over the editorship of the IRB from Hughes in 1963. Dengerink (1963) takes a brief look at the first ten years of the IARFA. He mentions the conferences and literature work. He then examines 'various trends' in Protestantism and describes the IARFA as having evangelical sympathies, but as its name suggests - is part of the Reformed movement. He stresses the whole range of creation aspects of the gospel:

'The purpose of this is that we must subject all our thinking and acting to Christ, and we must place all human relationships under the discipline of the Gospel.'

And

'The Reformed Christian is concerned with the entire Word for his entire life'.

He again stresses that IARFA is not an ecclesiastical movement, it has: 'interests in much wider areas than simply the Church itself. The programs of our international gatherings witness to this fact. The Kingdom of God is not limited to the church' (Dengerink, 1963:7).

All these are strong Kuyperian emphases. Dengerink gave the IRB a more Kuyperian focus. Hughes was much more Reformed than Kuyperian; Dengerink more Kuyperian than Reformed.

In 1964 there was an IARFA conference in Amsterdam which was reported on in IRB. The same issue has two pieces by
Britishers - but each with different views of Calvinism. In a sense these two articles (Duffield, 1964 and Hebden Taylor, 1964) characterise the polarisation within British Calvinism: a strong traditional, Old-School, aspect and a smaller Reformational trend. Both were dissatisfied with the state of Christianity in the UK, but their remedies were very different; for Hebden Taylor the remedy was to expose 'the hoax implicit in the claim to neutrality', whereas for Duffield it was through education and putting into the hands of the clergy good solid Reformed works.

D.M. Lloyd-Jones attended the 1953 conference, however, he wasn't too complimentary about it:

'I remember attending a conference in the South of France in 1953. And, to be honest and to be helpful, I have got to say this: I had to keep on reminding myself that I was in a Christian conference! I had to remind myself of it, because all the papers were entirely philosophical, and the arguments and disputations were almost entirely on that level. There was virtually no prayer at all. It was all a question of papers and of discussions, but it was a Calvinistic conference' (Lloyd-Jones, 1981).

He was perhaps reacting to the anti-pietistic attitudes of the neo-Calvinists and displaying his traditional Calvinistic viewpoint. Elsewhere Lloyd-Jones had been positive about the Kuyperian approach, commenting on Kuyper in 1975, in his address to the Westminster Conference, he said:

'The Christian is not only to be concerned about personal salvation. It is his duty to have a complete view of life as taught in the Scriptures. (...) As far as the Christian is concerned - and that is what we are interested in now - we are not to be concerned only about personal salvation; we must have a world view. All of us who have ever read Kuyper, and others, have been teaching this for many long years' (Lloyd-Jones, 1976:101).

However, there doesn't seem to be much evidence in LloydJones's writings of this perspective.

David and Ruth Hanson's first introduction to the IARFA - Hanson's father and mother had been part of the British 'Calvinist' contingent that visited the Netherlands with Atherton (Bishop, 2016a) - was in 1964, as 'conservative evangelicals reared on D.M. Lloyd-Jones' (Hanson, 2006). He notes:

'It was a turning point in our lives. The forbidding image of a Platonic Heaven, in which most evangelicals then seemed to believe, vanished forever. ('Where in the Bible, young man, do you find that you will spend eternity there with Christ?') The redoubtable Stacey Hebden Taylor (Vicar of Greengates, Bradford), Bernie Zylstra, Dengerink, van Riessen, Schrotenboer, Stanford Reid, Herman Ridderbos, Klaas Runia, Pierre Marcel became our friends and encouraged us.' 
Hanson also notes:

'A Charity, IARFA(UK), was registered [in 1976] to support the international association and propagate a Kuyperian worldview in this country but never really got off the ground. We never had ecclesiastical members - only individuals. Our interest was primarily in the full-orbed life-in-the-world of the people of God (church-life included.) The focus fell not so much on theology as on action recruited or invaded by the Kingdom of God in family and marriage, art and science, state and school, political party and industrial or commercial enterprise, labour union and private association.

For various reasons IARFA came unstuck both internationally and in the UK. Its administration was concentrated on very few, widely dispersed, people who could rarely meet. It suffered from chronic financial difficulties... In 2006, its 21st year, WYSOCS incorporated IARFA(UK) and adopted the latter's charitable registration' (Hanson, 2006).

We will pick up on the story of WYSOCS later. Although IARFA, as the name suggests, was international, there was some considerable British involvement in it. David Hanson was later responsible for organising several IARFA conferences in the UK and took over the editorship of IRB in 1977. When P.E. Hughes had moved to the States in 1964, Hanson took over his role of National Secretary and Correspondent for England. He became the Hon. Gen. Sec. of IARFA in 1974. In IRB 59 he provides a brief outline of the history:

'Almost fifty years ago, preparatory moves were being made in a very chastened Europe, for what emerged (in 1932) as the First International Calvinist Congress. My own parents were involved; my father, whose previous experience of continental Europe ended on a stretcher in 1917, took part in a contact-making visit to the Netherlands in 1928 led by an English clergyman, the Rev. Henry Atherton. At the first Congress, Langenohl and Lecerf represented German and French Reformed Christians respectively - Lecerf, the mentor of our own Dr Marcel; Langenohl, who himself played a part in establishing I.A.R.F.A. in 1953. A succession of those Congresses was disrupted by the Second World War, but out of the relationships then established emerged our association. A fascinating memento of this history was presented to us at the Conference just held in Holland - a letter sent by Colijn the then Dutch Premier, to Dr Rudolf Grob (I.A.R.F.A.'s first President, whose coming to Woudschoten this year touched many hearts), describing the contacts newly made with Atherton, the Englishman, and the hope then arising for an International Reformed enterprise. Of this, and of much more, we are the inheritors in the goodness of God' (Hanson, 1974).

From 1977 (IRB 69) onwards the editorial work was concentrated in the UK, Hanson was the General editor and Lance Bidewell (managing editor and treasurer) from London, and John Wilson (news editor) of Motherwell, Scotland. The general editor and managing editor were assisted by Hazel Bidewell, Ruth Hanson and Rosamunde Reich. It ceased publication in 1981.

There were a number of IARFA conferences. Three took place in Britain in 1961 ( $4^{\text {th }}$ in Cambridge), 1968 ( $6^{\text {th }}$ in Nottingham) and 1976 (10 ${ }^{\text {th }}$ Edinburgh). Others included:

- 1955 2nd Detmold, Germany: 'Man and World under the Lordship of Jesus Christ'

- 1958 3rd Strasbourg, France: 'How to Confess our Reformed faith'

- 1964 5th Woudschoten, Zeist, The Netherlands: “The Place and Task of the Church in the Modern World'

- $\quad 1970$ 7th Mittersill, Austria: 'The Spirit of Revolution and the Rule of Christ' ${ }^{4}$

- 1972 8th Bievres, France: 'Man - God's trustee in creation' ${ }^{\text {'5 }}$

- 1974 9th Woudschoten, Zeist, Netherlands: Christ - our Peace $^{6}$

Two Britishers were involved as speakers at Zeist: 'Reconciliation in work and industry' by Alan Storkey and the Conference sermon by Fergus MacDonald.

- $197711^{\text {th }}$ Aix-en-Provence, France, Christians and the future

- $\quad 198012^{\text {th }}$ Louvain, Belgium.

\subsection{The UK conferences}

A report on the $4^{\text {th }}$ IARFA conference at Newnham College, Cambridge 11-18 August 1961 was given in IRB 8 (Dengerink, 1962a). The theme was 'The authority of the Bible' and the congress secretaries A.R. James and Gervase Duffield, the president was Philip E. Hughes. The speakers at the conference included: Roger Nicole (USA), D.W.B. Robinson (Australia - later Archbishop of Sydney), A.M. Donner (Luxembourg - President of the European Court of Justice) and J. Marcellus Kik (USA), and from the UK James Packer, Herbert Carson, ${ }^{7}$ and Hughes.

Nottingham was the location of the $6^{\text {th }}$ conference on 'Christian education' in 1968. This was organised by David and Ruth Hanson - they were helped by Rex Ambler who was living and lecturing in Nottingham at the time. In a report in the

\begin{tabular}{l}
\hline $4 \quad$ Many of the papers were published in IRB 44-45 (1971). \\
$5 \quad$ A report is to be found in IRB 52-53 (1973). \\
$6 \quad$ See IRB 59 (1974) \\
$7 \quad$ At the time Carson was an Anglican minister in Cambridge, he later \\
became a Baptist minster.
\end{tabular}


Banner of Truth Geoffrey Thomas, who gave the morning Bible readings, notes that there were 55 visitors, 25 from the UK, from 15 countries (Thomas, 1968). Jan Dengerink gave the opening address. Other lectures included Paul Schrotenboer on 'The Christian school in a secular society'; James Mackintosh (Free Church College, Edinburgh) 'The Christian school in a missionary setting'; James W. Frazer (pastor of the Free Church of Scotland, Inverness) 'Upbringing in the Christian family'; Pierre Marcel 'Catechesis: The church's educational task'. ${ }^{8}$

Thomas (1968) reports that Paul Helm's 'The presuppositions of religious education' caused a stir - there was a vigorous question time in the morning which extended to a two-hour session in the afternoon.

In 1976 Carberry Towers, Edinburgh, with the theme 'God the creator', was the setting of the $10^{\text {th }}$ conference. Again it was organised by David and Ruth Hanson. The lectures included Jan Dengerink ('God-Creator of heaven and earth'); Egbert Schuurman ('Technology in Christian perspective)'; W. Stanford Reid ('The presence of God and the hope of man'); Hector Cameron ('Prayer in a closed universe'); and Pierre Marcel ('God the creator and the Christian's suffering'). ${ }^{9}$

Also involved in IARFA as a conference speaker and as a contributor to the IRB was Stacey Hebden Taylor.

\section{STACEY HEBDEN TAYLOR}

It was in 1963 that Hebden Taylor returned to England from Canada having been converted to a Reformational approach. Revd Eustace (Stacey) Lovatt Hebden Taylor (1925-2006) was the son of African missionary parents. He was born on 25 July 1925 in Katanga, Belgium Congo, now known as the Democratic Republic of Congo. Hebden Taylor was one of the first Britishers to make use of a Reformational perspective (Bishop, 2016b).

After his post-war conversion at Cambridge University he became convinced that 'Anglicanism was the most purely and truly "catholic" expression of Christianity' (Hebden Taylor, 1960). However, although he felt a calling to ordination he couldn't hold to the establishment of the Church of England, where a 'secular' British government appointed bishops. His views on the relationship between church and state were already beginning to take shape: 'In my opinion it is NOT the business of the Church of God to provide the ideological cement for any political or economic power.'

He then considered emigrating and being ordained in another Anglican province. The choice was either New Zealand or Canada. One of Stacey's ancestors had served as a soldier in Quebec during the 1812 war, and that was enough for him to decide to go to Canada. So in August 1949 he left England for Canada and went to work in Vancouver with the Hudson's Bay Company. Several of the papers were published in IRB 36-37 (Jan/ April 1969)
It was during the early sixties that Stacey became familiar with the Reformational perspective. This was in part from reading Henry Van Til's book The Calvinistic Concept of Culture. In the foreword to the second (paperback) edition Hebden Taylor writes:

'It is with pleasure that I welcome the publication of this important book in a paperback edition, thus making it available to a wider audience, especially to students. It was partly by reading this book in 1961 that I recovered my faith in the full authority of the Word of God over the whole of human life, society, and culture' (Hebden Taylor, 1972: 9).

And in part also through meeting a number of Canadian and North American Reformational thinkers. In the preface to his Christian Philosophy of the Law, Politics and the State, he acknowledges his debt to several of them:

'I would also thank my esteemed Christian brothers, Bernard Zylstra, Gerald Vandezande, Harry Antonides and Professors H. Van Riessen, J.M. Spier, H. Evan Runner and A.L. Conradie for bringing me in touch with the most exciting intellectual development in Christian thought since the time Thomas Aquinas wrote his famous apologies in defense of Christian truth as he then understood it. I would especially thank Bernard Zylstra for his enthusiastic help in so many directions and for his guidance in the interpretation of Dooyeweerd's thought' (Hebden Taylor, 1966).

Elsewhere he describes Dooyeweerd as "my spiritual "father"' and H. Evan Runner as his 'holy uncle' (Hebden Taylor, 1970:xii). Embracing Reformational thought was not just a theoretical change; he also became involved in the then ten-year-old Christian Labour Association of Canada (CLAC). In March 1962, he presented a paper for them on the need for Labour Unions; this was subsequently published (Hebden Taylor, 1962). It was also in 1962 he became involved in a dispute with the Anglican hierarchy in Toronto. A report for the Bishop of Toronto made it clear that plural representation of labour was a peculiarly Dutch concept and would not work in Canada (Summers, 1962). In the report Summers also (falsely) maintained that CLAC was using the union meetings as a means of seeking conversions to Calvinistic theology. Bishop Hunt refused to permit Hebden Taylor to assist CLAC in their struggle with the Ontario Labour Relations Board.

Hebden Taylor, it seems, had a number of conflicts with Bishop Hunt and this in part prompted his move back to England. It was this newly-found Reformational perspective that had brought him into conflict with Hunt and it was this perspective that he took back with him to England.

The Hebden Taylors returned to England in 1963, where Stacey began ministry as a curate at St Mary the Virgin, Langley Marish, Berkshire and then later became vicar of Greengates, Bradford from 1964 until 1969. It seems his views on church and state didn't prevent him from taking up a leadership role in the Church of England. 
He brought back with him to England a strong Dooyeweerdian perspective. It was this thinking that saturated his books written during this time. One of his major works, The Christian Philosophy of the Law, Politics and the State, was written during this period. It was also during this time he got to know Elaine Storkey (née Lively). Storkey had been put in touch with Hebden Taylor by Paul Schrotenboer when she returned to England from studies in Canada (Storkey, 2014).

In the UK Geoffrey Thomas, a graduate of Westminster Theological Seminary and the minister in Aberystwyth wrote a positive review in the Banner of Truth. Colin Brown ${ }^{10}$ in the Churchman observed:

'It might justly be said that this book is too long. It is therefore all the more odd that in a work of such massive proportions, written by an Anglican, dealing with the subject of church and state, no mention is made of Jewel and Hooker, and no discussion is offered of the Reformed Anglican position' (Brown, 1967:132).

This indicates how far apart the Calvinism of the Reformational and the traditional Calvinists was.

Elaine Storkey observes:

'Dooyeweerd wrote to him and said he didn't know whether he had greater admiration for him as the author of the book, or the publisher who was willing to take the risk of publishing! I visited Dooyeweerd in the Netherlands and he said he had been flattered by Stacey's commitment' (Storkey, 2014).

If Hebden Taylor had thought this book would open up an academic career for him in Britain he was sadly mistaken. He was not short-listed for any of the academic posts that he applied for. The book was, however, instrumental in obtaining him a professorship at Dordt College. It was at Dordt that Hebden Taylor continued in the Reformational tradition. He never returned to Britain. He remained at Dordt College until 1982 when he became the rector of St Alban's Anglican Church, Tacoma, Washington. He retired in September 1983 and died on 1st September 2006.

\section{MIFCU}

The Manchester Inter-Faculty Christian Union (MIFCU) was at one time another centre of Reformational philosophy. MIFCU met at Ivy Cottage Evangelical Church every Saturday evening to hear a lecture and discussions with prominent Christian academics. Both Rex Ambler and Irving Hexham had been introduced to a Reformational approach there.

The Canadian Clark Pinnock (1937-2010) had come to Manchester in 1960 to study for a PhD under F.F. Bruce. Pinnock, after completing his $\mathrm{PhD}$ in 1963, became an assistant lecturer relegated to a footnote (Brown, 1969:246 fn 8) - there is no mention of Kuyper at all.
(1963-65) (Price, 1988:158; Roennfeldt, 1990:73). During this time he came under the influence of Francis Schaeffer. Pinnock visited L'Abri as a student and as a worker. He encouraged students to read Schaeffer and Van Til. ${ }^{11}$ Hexham (1970) writes:

'[A] group began at Manchester University when a Christian tutor [Pinnock] there encouraged some students to read Van Til's Defence of the Faith. One of these students went on to read Dooyeweerd [this was Trevor Watts - see below]. He then interested other students in Dooyeweerd's ideas. From this group one student is lecturing in Philosophy at a University in Canada while another is doing research at the Free University in Amsterdam' (Hexham, 1970:41).

It was also during his time as a PhD student in Mathematics at Manchester that New Zealander Duncan Roper became aware of the Reformational perspective. In 1963-64 Roper became good friends with Graham Birtwistle. Hexham and Roper both went to visit L'Abri in Huemoz, Switzerland, in $1966 .{ }^{12}$ Roper returned to New Zealand in 1966 with this new-found perspective where he helped form the Foundation for Christian Studies in 1973 (Simons, 2006). After Birtwistle graduated from Manchester he lectured in art history at Leicester Polytechnic (1964-70), and went on to teach modern art history at the Free University (VU) in Amsterdam (1971-2004).

Paul Marshall (b 1948) was a member of the Christian Union at Manchester. He graduated with a degree in Geology in 1969. He discovered the writings of Francis Schaeffer and spent some time at L'Abri. He then encountered papers written by Harry Antonides, H. Evan Runner and Dooyeweerd's A New Critique of Theoretical Thought. His interest in political theory overtook his interest in geology and after obtaining an MSc from the University of Western Ontario, he enrolled at the Institute for Christian Studies (ICS), Toronto in 1971 to study with Bernie Zylstra. In 1980, he returned to the ICS as a part-time professor in political theory after obtaining an MA and PhD from York University, Toronto. He became a senior member of the ICS in 1980.

Rex Ambler discovered Reformational thought when he was a student studying philosophy and arts at Manchester University. He had previously heard D.M. Lloyd-Jones preach and had been taken with the Reformed approach. It was through meeting with a medical doctor Bill Crimmin who was a book agent for Presbyterian and Reformed books that he came across the Kuyperian perspective. Crimmin was a Van Tillian. Ambler went to Oxford in 1960 to study theology. There he met with Jim Packer, then at Latimer House. Packer encouraged him to go to Amsterdam:

$11 \quad$ Pinnock drifted from his Calvinism towards Arminianism when at Trinity Evangelical Divinity School. His first two books Set Forth Your Case (1967) and A Defense of Biblical Infallibility (1967) show the influence of Schaeffer (see e.g. Steen's extensive and discerning review (1968)), though in a second edition of the former he adds an evidentialist approach to his 'cultural apologetics'. 
'If I was to come to terms with Van Til's philosophy. Lloyd-Jones advised me similarly, but both warned me against the intellectualism of Amsterdam and its lack of warm spirituality. I took their advice, and their warning, and studied theology for one year, under Gerrit Berkouwer, and philosophy for one year, under Dooyeweerd, van Riessen, Zuidema and van Peursen (Ambler, personal communication 2013).

While in Amsterdam Ambler was visited by David and Ruth Hanson where they first met Bernie Zylstra. Ambler later helped organise the 1968 IARFA conference in Nottingham with the Hansons. However, Ambler was not impressed - as Lloyd-Jones and Packer intimated he might not be - with Reformational spirituality. They seemed 'over-dogmatic, formal and defensive' (Ambler, personal communication 2013). On his return to the UK Ambler delivered a paper on Kuyper at the invitation of Packer for the Puritan and Reformed Studies Conference, held at Westminster Chapel in December 1967. This is the first paper published on Kuyper by a Britisher (Ambler, 1967); Ambler describes it as his swansong. Ambler later moved away from Reformed circles and is now an active member of the Quakers (see, for example, Ambler, 2013).

Irving Hexham (b. 1943), professor of Religious Studies at the University of Calgary, ${ }^{13}$ Alberta, Canada was also a product of MIFCU - although not technically a Manchester student. Hexham, a gasfitter at the time, was introduced to MIFCU by Peter Heyman in 1960. At MIFCU he met Trevor Watts, an army officer studying dentistry. Watts was able to afford many of the expensive Presbyterian \& Reformed books, which he generously lent to anyone who was interested; he did much to popularise the ideas of Van Til and Dooyeweerd. ${ }^{14}$ Hexham was encouraged to visit L'Abri by Jillian Jackson, a school teacher at his local church, St Phillip's, Cheadle. There he met Francis Schaeffer who 'profoundly influenced his thinking'.

'At L'Labri I met Francis Schaeffer and Hans Rookmaaker. What impressed me about Schaeffer was that even though I had never gone to university he spent a whole morning talking with me in his upstairs study. This was noticed by a visiting professor from an American Christian College who actually complained rather loudly that Schaeffer has "wasted his time" talking with an "uneducated worker:" At the time I was actually no longer an apprentice but a manager with the North Western Gas Board in Ashton-UnderLyme' (Hexham, personal communication, 19th February 2016).

\footnotetext{
13 A recent Festschrift for Hexham was Border Crossings: Explorations of an Interdisciplinary Historian, edited by Ulrich van der Heyden and Andreas Feldtkelle.
}

Irving Hexham, personal communication, 19th February 2016. After graduation Watts was posted to Germany and so was never involved with others in the UK who had a Reformational vision. He has recently retired as a consultant in periodontology at Guy's Hospital, London and has been a past president of the British Society of Periodontology.
After his visit to L'Abri he was in contact with Schaeffer's son-in-law Ronald Macaulay, who was then living in London. Macaulay contacted Hexham to say that Schaeffer was visiting the UK in February 1966. Hexham helped arrange a visit to Manchester where Schaeffer spoke to an MIFCU student group on 'Existentialism, Humanism, Christianity ... Which works?' As a result of this visit Graham Birtwistle and Jerram Barrs got to know Schaeffer.

Hexham then became a lecturer in gas technology at the Gas Board's Training School, which was affiliated to Stretford College. At the same time he was in his own time studying for his A-levels through a correspondence course. After his A-levels he hitched to L'Abri with Jerram Barrs ${ }^{15}$ and Mike Tymchak. ${ }^{16}$ He spent the summer at L'Abri. Here he got to know Rookmaaker better:

'When I [Hexham] asked [Rookmaaker] why Schaeffer's links to Dooyeweerd were not clearer he said that he had discussed how to present Dooyeweerd's basic framework and insights to a wider audience than Dutch Calvinist circles and both were convinced that one had to translate Dooyeweerd's ideas into less technical language. In fact, Rookmaaker was quite critical of many Reformational thinkers for being too technical and tending towards jargon.

These and later conversations with Rookmaaker convinced me that the way forward was to translate Reformational terms and thinking into more normal English. This can be seen in the book I wrote with my wife, Karla Poewe, Understanding Cults and New Religions (Eerdmans, 1986). It contains no mention of Dooyeweerd or even Kuyper but is shot through with their approach to religion and society' (Hexham, personal communication $19^{\text {th }}$ February 2016).

Irving Hexham encouraged by Schaeffer, Macauley and others after completing a gasfitter's apprenticeship and becoming a manager with the North Western Gas Board, obtained university entrance qualifications and completed a BA at the University of Lancaster in Religious Studies where he worked with Ninian Smart and Edward Conze. He then moved to Bristol to study under F[red] B[urkewood] Welbourn for his MA (Hexham, 1972b). Welbourn was not Reformational, yet had an almost Reformational view of religion:

'Religion is what religion does. (...) What is religion? Nobody has yet given a satisfactory definition. All that this book can do is to describe certain actions and

$15 \quad$ Barrs graduated from Manchester in 1967, he then went to work as a staff member at L'Abri in Huemoz. He was the founding member of L'Abri Fellowship, Hampshire, England and later the director (19711988). He has since 1988 been director of the Francis A. Schaeffer Institute at Covenant College, St Louis, MO, USA.

16 Tymchak came to Manchester in 1963 to study for a $\mathrm{PhD}$ in philosophy; he stayed on for a further year to teach philosophy and was involved with International Fellowship of Evangelical Students (IFES). He is now at Regina University, Saskatchewan. 
beliefs which are generally regarded as religious, to discuss their function in human life and to ask what is the character of other actions and beliefs, which seem to fulfil the same functions but are not normally regarded as religious. What do we mean by such statements as 'Smith makes a religion out of cricket', 'Communism is essentially a religious movement although it debunks religion'? Is psycho-analysis any less a religion than is an ancestor cult? By studying some African religious beliefs and practices we may reach a better understanding of our own society' (Welbourn, 1968:7-8)

Hexham completed his $\mathrm{PhD}$ at Bristol University in the Department of History where he was supervised by Kenneth Ingham. This involved almost three years' research in South African archives. While in South Africa the University of Bristol appointed Elaine Botha as his local supervisor.

After completing his research he moved to Derby where he wrote his thesis while an assistant professor at Bishop Lonsdale College, University of Derby. He worked there from 1974 until 1977 when he moved to Canada. While still an undergraduate at the University of Lancaster, Hexham got to know Richard Russell with whom he cooperated in organising a conference.

\section{RICHARD RUSSELL AND THE CSU}

One of the most influential resources that helped introduce many to the Reformational movement and resourced many more was the bookselling and networking of Richard Russell and the Christian Studies Unit.

Richard A. Russell was a geography/education and philosophy student at Aberystwyth when he was converted and introduced to the Reformational perspective. As he puts it:

'Within weeks of conversion I was given a set of the Unionville (Ontario) Lectures by leading Dutch and Canadian academics (Van Riessen, Runner, Hart, Zylstra, etc.) which had been sent to UCCF (then IVF) headquarters in London and given to Geraint Fielder, UCCF travelling Secretary for Wales who in turn handed them over to me. By the autumn term I had a proto-CSU (Christian Studies Unit) bookstall next to the UCCF bookstall at the CU every Saturday night - often outselling them, which gave me considerable satisfaction. ${ }^{17}$ I went through an intense spiritual crisis - I saw that Christ must be everything -- all things were made by him, upheld by him and made for him. In short, any sort of natural/spiritual dualism was impossible as was the idea that there could be religious neutrality in any branch of knowledge. One of my fellow philosophy students was Elaine Storkey (then Lively) who had come up to college as a Christian already' (Russell, 2006). who ran the Craig Press and Presbyterian \& Reformed Agency in the UK.
In 1965, he and Elaine Storkey were awarded Teaching Fellowships at McMaster University in Hamilton, Ontario. There they met Paul Schrotenboer, who lived nearby, and Adrian Guldemond, a philosophy student at McMaster, and attended one of the Unionville Conferences.

Elaine Storkey returned to Britain in 1966 to a research fellowship in philosophy at York University. It was there that she came into contact with E.L. Hebden Taylor.

Russell went as a special student in Apologetics to Westminster Theological Seminary to study under Cornelius Van Til and Robert Knudsen. There he spent a lot of time with fellow students James Skillen, William Edgar and James Hurley.

Russell returned to the UK with his MA in 1967 (Russell, 1967). His bookselling and networking did not stop. The first CSU booklist was printed on a Banda machine at Ashton Park School in Bristol in May/June 1967. Richard was a temporary geography teacher there, filling the shoes of a recently deceased teacher.

The next year he did supply teaching while living in a hut in his parents' garden at Keedwell Hill, Long Ashton, Bristol. Thanks to Elaine Storkey in October 1967 he obtained a position at Manchester College, Oxford and moved into rooms. Storkey had previously been a part-time tutor there before taking up a research fellow post in sociology at Stirling University, Scotland when she married Alan Storkey. At Manchester College, Alan Passmore and Douglas Holt were members of Richard's philosophy group. ${ }^{18}$ Chris Sugden and other remembers of the OICCU committee came along but left when they realised that Reformational thinking involved a critique of many aspects of their conservative evangelicalism and that it implied that the evangelistic priority should be at least supplemented by serious academic discipleship; it was about the formation of Christian students rather than Christians who happened to be students. A very close friend and fellow student of Chris Sugden was Tom Wright who never came along and may possibly have been warned off by Sugden. It would be some years later that Wright would run into Brian Walsh at McGill University (Canada) where Walsh introduced Wright to some of those who espoused the Reformational approach. This was the period when Walsh and Middleton were completing The Transforming Vision.

A frequent visitor to Manchester College was Arthur Jones. He was working on a PhD at Birmingham University - developing a critique of theories concerned with the alleged evolution of fish. He and Russell struggled with relating contemporary philosophy of science to evolutionary theorising.

Manchester College's Unitarian leadership refused to renew the contract of two lecturers - Russell and his friend and colleague Dave Pithers (who taught social studies). Pithers was the leader of the Revolutionary Socialists in Oxford. They were seen as problematic during the tumultuous years of 1968-69. 18 Douglas Holt became a canon theologian at Bristol Cathedral and
Alan Passmore a solicitor in Derby. 
In March 1968, the Russells went to a L'Abri conference at Ashburnham Place, Sussex and there for the first time heard and met Francis Schaeffer and talked at length with Hans Rookmaaker. This relationship continued until shortly before Rookmaaker's death in 1977. At their last meeting Rookmaaker reproached Russell: 'Richard you have written some rather critical things about my friend Francis. ${ }^{19}$ He continued 'I completely agree with what you have written but Francis is now too old to change his thinking. It is my great regret is that I failed to insist that Schaeffer should read and understand Dooyeweerd for himself rather than borrow bits and pieces secondhand from me'.

Russell at this time was also involved in the IVF Graduate Christian Fellowship Philosophical Apologetics Group convened by Donald M. MacKay (1922-1987). ${ }^{20}$ Other members included Paul Helm, Oliver Barclay, Stewart Sutherland, Rex Ambler, Elaine Storkey, Colin Brown, Haddon Willmer and Anthony Thiselton. Russell gave a paper looking at the possibility and necessity of Christian scholarship, but it was received with some hostility, particularly from Donald McKay. Stewart Sutherland wrote a paper in response (Sutherland, 1969). The group soon disbanded. MacKay later wrote a letter asking Russell what the Christian way to boil an egg was. This was a typical British response to Christian Philosophy. The preferred philosophy was rational empiricism. MacKay had been greatly influenced by another Dutchman Reijer Hooykaas (1906-1994) whom he first met in 1948. Hooykaas was a professor of history of scienceatKuyper's VU, butwas noally ofa Dooyeweerdian philosophy and rejected the notion of a Christian scholarship; for Hooykaas there was: "No call for the "Christianizing" of disciplines or the "inner reformation of the sciences"' (Leegwater, 1996).

In July 1969 Russell married Janice - a young Bristol Art College art student whom he'd been helping with a dissertation (Art and Philosophy in the $20^{\text {th }}$ Century). A call from Calvin Seerveld in September 1969 meant that he and Janice took up posts at Trinity Christian College in Chicago (TCC). His predecessor was Pete Steen who had suddenly moved to Geneva College. At TCC were Calvin Seerveld, Robert Vandervennen, Marten Vrieze, Emily Brink, Calvin Jongsma, Arnold De Graaf, C.T. McIntire, Lou Voskel, Rockne McCarthy and Arie Leegwater - who were working on developing an integrated Reformational curriculum. The new president, Gordon R. Werkema, came in 1969. During his time there Richard recalls reading van Den Berg's biography of Kuyper in front of a fire at the farm of Bob and Barbara Carvill: 'It felt like a homecoming ... I was in tears'.

Among the students whom Richard taught were John Kok (recently retired as a philosophy professor at Dordt College), Justin Cooper (former president of Redeemer College), James Rusthoven (emeritus professor of medicine at McMaster University) $^{21}$ and Ed Echeverria (now a philosophy professor in Detroit).

19 These were book reviews in IRB and Vanguard.

20 A brief but helpful look at MacKay is Haas (1992)

21 Rusthoven competed a $\mathrm{PhD}$ at Trinity College, University of Bristol in October 2011, it was published as Rusthoven (2014).
In the intervening time a number of conferences took place in the UK (Keddie, 1970; Hexham 1971, 1972a). The first conference of the AACS (Association for the Advancement of Christian Scholarship) took place in Birmingham 1970. Surprisingly, the UK AACS and IARFA didn't have any formal links.

Gordon Keddie in the Banner of Truth reports on what he describes as 'The first conference of the A.A.C.S.' (Keddie, 1970). It took place on 17-19 July 1970 at St Peter's College, Saltley, Birmingham. The main speaker was Robert Knudsen, Arthur Jones who had just completed his $\mathrm{PhD}$ from Birmingham helped to organise the conference and spoke on 'A Christian Scientist at work'. Danie Strauss recalls attending.

A second AACS conference was held at St Mathias College, Bristol (Hexham, 1971). Richard Russell, Janice Russell, Jan Dengerink and Graham Birtwistle were among the speakers. Revd Tony Baker led a reflection on Psalm 8. The committee comprised Richard Bibby, Irving Hexham, Julie Holborn, Fred Jones, John Neal, Alan Passmore and Ruth Perry.

Baker was the vicar of Redland Parish Church, Bristol. Richard Bibby and Hexham were friends from MIFCU and Alan Passmore got to know Russell when he was at Manchester College. Dengerink's involvement had come through his IARFA links. Russell, still based in Chicago, gave 'a simple yet profound analysis of the basic tenets of Dooyeweerd's philosophy' which was 'greeted with enthusiasm by all present'.

Hexham (1971) notes that:

'A growing sense of identity and independence developed within the British AACS, a group that has been independently organized from the beginning, and which will henceforth be known as the Christian Studies Unit, a more British-sounding name for getting on with the serious task of witnessing to the modern British cultural scene.'

And Jan Dengerink in his second address made the important point that:

'Groen and Kuyper had addressed themselves to the problems of their day; now we must face the situation of our day. In the light of our own particular cultural situation we must work out our own Christian approach. To rely on Amsterdam or Toronto would be to fail to take seriously the Lordship of Christ over the British situation.'

The committee passed a number of resolutions, described as 'The British six-point agenda':

1. To hold a one-day conference in London on January 8th.

2. To hold a week-end conference the next summer, probably in Bristol, which would be followed by an intensive study week for those who wanted to really get to grips with things. 
3. To issue an explanatory leaflet about the history and aims of the BAACS.

4. To issue a short newsletter.

5. To establish some sort of fund which could be used to assist people who have to come long distances to attend our conferences.

6. To adopt a new name which will be better adapted to the British situation. After a great deal of thought it was decided that in the future we would be known as the Christian Studies Unit.

I have not found any evidence of 3 or 4 , but the London conference certainly took place on $8^{\text {th }}$ January 1972. Arthur Jones and C.T. McIntire gave the talks. It was held at the National Institute of Social Work and Training and attended by around 70 people - twice as many as they had expected. According to Hexham (1972a):

'Arthur Jones gave a brilliant survey of the philosophical assumptions underlying the so-called 'neutralist' positions of "modern scholarship", exposing their dogmatic basis. Having exposed the fallacy of "neutral" methodology, he then argued cogently for the establishment of a Christian Institute for advanced scholarship in Britain.'

C.T. McIntire followed Jones by showing the practical effects of hidden dogma in political and social life. His clear analysis of the 'counter-culture' was a challenge to all true Christians to repent for the failures of the Church in this area of life and to develop a true alternative to the Establishment - a Christian alternative.'

Colin Wright was one of the attendees. He would later translate Pierre Marcel's introduction to Dooyeweerd from French into English (Marcel, 2013a,b). He recalls that he was introduced to the Reformational movement by coming across Francis Schaeffer's books and Hebden Taylor's Christian Philosophy of the Law, Politics and the State while at Barry Bible College in 1968-1970. He too used Dr Milner's Reformed Book Club in Derby and obtained Kuyper's Lectures on Calvinism, expecting them to be about the five points.

Another conference was planned for July 1972 with H. Evan Runner. It was to be held at All Nations Christian College, Hertfordshire. Runner's topic was to be 'Religion and the total Christian Life'. Unfortunately, it had to be cancelled, as the number of bookings didn't justify putting on the event.

In June 1972, the Russells returned to England after having been fired by Werkema along with many others starting with the academic dean Bob Vandervennen. A number of these moved to the Institute for Christian Studies in Toronto and to Dordt College. Other firings soon followed.

During this time they lived in Bristol and Rusell completed his MA at Bristol University on Evangelicalism in Britain (Russell,
1973), he completed a PGCE in 1974 and still unable to find a job completed an MEd in 1976.

They became involved in the Bristol Arts Centre Group (ACG) $)^{22}$ which also involved Richard Winter and later Martin Kisko and Nick Park (the creator of Wallace and Gromit). The ACG although had many members who had a Reformational vision but for most the main concern was cultural apologetics.

Irving Hexham, then living in Derby, contacted the Russells and arranged for them to live rent-free at a house (33 South Street) owned by Revd Roger Crostwaite (b 1938) at St Werburgh's, Derby in return for helping out at the church. Richard also started to teach sociology part-time at the technical college in Derby for $£ 5$ per week.

1975 saw the Christian Studies Unit Summer School. It was modelled after the Communist University of London Marxist Conference. As Richard puts it, 'it was a seven-day gig'. He wanted to avoid the usual Christian house party approach of religion on Sunday, a walk on Saturday and the main event for 30 minutes on a Friday evening! It was organised by Andrew Thompson (now Thompson-Smith). He was an architecture student at Cambridge and an excellent organiser. Fifty or so people attended and $£ 400$ worth of books sold. The speakers were the Russells, the Storkeys, Tony Cramp, David Bebbington, (then a PhD student at Cambridge), David Lyon and Andrew Thompson. Those who attended included Antoni Diller, ${ }^{23}$ Philip and Miriam Sampson, Ruth Barton, Jim Bigelow, David Booth, Elmer Darnal, Pat Dearnley, Shirley Dex and Graham Ward. The topics were on philosophy, history and the social sciences. A winter CSU conference also took place at St Werburgh's (30 December 1975- 2 January 1976), this time the topic was science. The speakers were Arthur Jones, David Watts and Richard Russell.

During this time, Russell started a $\mathrm{PhD}$ thesis at Nottingham University in Education. At its core was the attempt to develop a theory about the unavoidable structure of any possible academic discipline. He argued that every discipline cannot but help assuming and specifying an ontology (field of investigation) conjoined with an appropriate epistemology (the appropriate type of concepts, theories and methods).

22 The ACG movement was initiated by Nigel Goodwin (Porter, 1993). Goodwin was highly influenced by Francis Schaeffer and Hans Rookmaaker (Porter, 1993:92-93). He was associated with Greenbelt and the 1968 Keele vocation conference which Rookmaaker attended (see below). Goodwin formed the Genesis Arts Trust in 1981 the board of reference included Calvin Seerveld.

23 Diller had been introduced to Dooyeweerd by Russell. Diller comments: 'I first heard about Dooyeweerd on Friday, the 3oth of November 1973, when Richard Russell gave a talk about him in the Latimer Room in Clare College. I think that this talk had been arranged by the Christian Union. I bought several books from Richard and was attracted by Dooyeweerd's ideas' (Personal communication 24 July 2015). Diller studied under Rex Ambler at Birmingham University for a MA on Dooyeweerd. He later became more critical of Dooyeweerd's approach (Diller, 1990). 
These form the philosophical presuppositions of every discipline. In turn these philosophical positions depend themselves on religious presuppositions - whether pagan, Christian, humanist or various synthetic combinations. So, too, education, which involves the discipline taught, combined with the theories that constitute educational theory and underlie its practice - philosophy, sociology, psychology, history, politics, etc. Consequently, no education can be philosophically or religiously neutral. Consequently, such distinctions between secular education and faith-based education are spurious and serve the purposes and advance the cause of humanism. A key part of the thesis was to use the proposed theory of disciplines to make explicit the diverse philosophical and religious presuppositions behind a wide spectrum of disciplines. The whole thing was worked out but unfortunately not completed - it was overtaken by ordination training.

Revd Crosthwaite moved in 1978 for a sabbatical to the States. Care of the church was taken over by an Anglo-Catholic vicar in a nearby parish which made life very difficult for the congregation.

Revd Tony Halsey, the then curate and an ex-lawyer, suggested to Richard he 'turn his collar around', then he could get paid for doing what he was doing at present! At the same time all the part-time staff at the college in Derby were made redundant, Richard included.

Richard pursued the idea of ordination. At his first Bishop's advisory panel he felt that his ironic humour sabotaged his chances as it didn't go down well with the retired Admirals on the panel. His second was more successful. In the meantime, he had been sorting parcels ( $11 \mathrm{pm}-7 \mathrm{am}$ ) in an unheated station and driving trucks for Rail Express Parcels every other week. He began his ordination training at Trinity College Bristol in 1979-80.

During this time, he had a college placement at the University of Bristol with the interdenominational Monica Wills Chaplaincy as an assistant to the chaplain Revd Steve Abbott (Russell, 1980). The chapel was orthodox evangelical with a strongly charismatic approach. This placement was taken as Richard hoped to go into university chaplaincy work after a curacy. This came from a:

'longstanding concern about the implications of the Christian faith for scholarship and the growing conviction that the Christian witness in and to the modern university falls so short of why it should be' (Russell, 1980:1).

His work had three main areas: preaching, Christian basics seminar and counselling. During this time he attempted to show:

$\therefore$ in detail from a number of disciplines how the Christian students were being regularly and methodically won over to the fragmented secular mind of the university without then being even conscious in the process' (Russell, 1980:3)
He was also involved in running two six-week 'Christian basics' groups. In these he covered a wide range of topics in relation to the Christian faith including creation and evolution, scientific method, philosophy of science.

Here Russell met Mark Roques, Pete Core and Steve Smith. Both Roques and Core went to study at ICS, Toronto and later joined St Matthew's, Widcombe when Russell became the vicar several years later.

He had a mixed reception from the Trinity lecturers. Tim Bradshaw allowed Russell to teach part of his doctrine course dealing with Aquinas, Kant and Hegel but the philosophy and ethics lecturer viewed him as intellectually arrogant and unteachable, in part perhaps because Russell challenged his marking of his paper on theodicy.

He completed his Diploma of Higher Education (Theology) in 1981 but was unable to find an appropriate curacy. After much searching he eventually became curate at St Paul's, Hartlepool (1982-1985). This was a difficult period for Russell and his family, not least because it was a dying Anglo-Catholic parish, the previous curate had been a Freemason and the priests in the diocese relentlessly drove their curates into the ground. During this time there were no CSU conferences, although the bookselling continued as well as the networking and many visitors. Those from the south usually arrived late and made remarks like: 'I didn't realise people lived so far north!'.

He was ordained in 1982 by John Habgood - after reading some of Russell's writings he, at first, refused to do so until the last minute. ${ }^{24} \mathrm{He}$ was later priested in 1983 by the notorious David Jenkins.

Apart from taking part in two services every day in an empty church his main ministry turned out to be the Cleveland and District Churches Unemployment Programme of which he ended up as chairman. It was funded by the Manpower Services Commission. This involved setting up numerous projects for and with unemployed people in Hartlepool - including a professional recording studio, a yacht club, classes on cheap and healthy eating and cooking. The Programme also took over the old customs house on Hartlepool Docks and set up a workshop. Among other things, it manufactured cannon balls, ramrods and buckets for HMS Warrior which was being restored there; it is now next to HMS Victory and Mary Rose at Portsmouth.

One academic contact in Hartlepool was Geoff Hall who was an unemployed electrician. Russell encouraged him to leave Hartlepool and 'get an education' - so he did a BA in Art History (Bristol) and an MPhil in art education (Exeter), and he now runs an arts project in Bristol. Richard and Janice were also assistant missioners at St. John's College, Durham for one year. Richard also gave a series of talks to a group of Christian modern languages students at St. Johns - covering Descartes, Rousseau, Kant, Hegel and Sartre. Russell (1984) provides a critique of Habgood's Church and Nation in
a Secular Age. 
Russell was looking for university chaplaincy posts, but nothing was materialising. He then had a phone call from Tony Walter (now professor of Death Studies, Bath) a member of the Ilkley Group (see below) asking him to apply for the post in Widcombe, Bath. He became priest-in-charge of St Mathew's and St Thomas, Widcome, Bath in 1985 and then vicar in 1988.

Here the CSU flourished. A number of day and weekend conferences were held.

Conferences included:

- 1988 November 'Political philosophy in Christian perspective' with Jonathan Chaplin. He explored the philosophies of liberalism, conservatism and socialism and then the basis for a Christian political philosophy and received a standing ovation. The usual conference fee of $£ 10$ was charged for a full Saturday conference.

- 1989 An Open Christian College Land conference was held on May 26-28 with Mark Roques, Alan Storkey, Arthur Jones and Tim Cooper.

- 1990 Paul Marshall (June 1990 on Human Rights)

- 1991 Brian Walsh and Dave Tomlinson (May)

- 1992 'Amoeba and us' with Arthur Jones (January).

There was also a weekend arts conference - where some travelled from the Isle of Lewis, but hardly any travelled from the neighbouring parishes. One vicar later confessed to Russell that they didn't advertise the events as they were scared of losing members of their congregation to St Matthew's, which had become a lively and youthful congregation.

Russell also taught philosophy of religion for a term at Trinity College, Bristol. He also taught courses for Bristol University Dept. of Extra-mural education in both the philosophy and theology sections.

Johnny Baker (CMS pioneer mission) and Gerrard Kelly (Bless Network and Spring Harvest) were both members at one time of Russell's congregation in Widcombe, while they worked for Bath Youth for Christ, which was based in St Matthew's old vestry. Musicians Adrian and Sue Snell moved from Leeds to join St. Matts too.

Richard Russell retired from parish ministry in 2000 and now lives in Somerset but still carries on bookselling, mentoring and networking.

One of his monthly involvements is with the philosophy group of the Bath Royal Literary and Scientific Institution. He gets to give a lecture there annually with titles like 'What has Reason ever done for us?, a fresh look at the history of western philosophy' and 'How serial idolatry has ruined modern western philosophy.'

\section{HANS ROOKMAAKER}

Hans Rookmaaker had great influence on the British university scene. Hexham notes that:

'Importantly, Rookmaaker was an old friend of Francis Schaeffer and one of the founders of the L'Abri fellowship. A disciple of Dooyeweerd, Rookmaaker believed that Reformational thinking needed to be freed from jargon and translated into ordinary language which is what he attempted to do in his talks and books. Through him Schaeffer adopted what was essentially a Reformational position that was developed in popular form as a result of his constant interaction with Rookmaaker' (Hexam, personal communication, 22 February, 2016)

As Heslam - perhaps with a little overstatement - notes:

'It is Hans Rookmaaker (1922-1977), professor of art history at the Free University from 1965 to 1977, who was largely responsible for establishing the Kuyperian tradition in Britain' (Heslam, 2013:361).

Rookmaaker was particularly influential on those involved in the arts not least Graham Birtwistle and E. John Walford. ${ }^{25}$ His Modern Art and the Death of a Culture was published by IVP, the publishing arm of the Inter-Varsity Fellowship in 1970 (Rookmaaker, 1970). They also published in 1978 his Art ... Needs no Justification (Rookmaaker, 1978).

Graham Birtwistle first heard of Rookmaaker in 1965 from a UCCF/ IVF ${ }^{26}$ Travelling Secretary ${ }^{27}$ (Martin, 1979:126). Rookmaaker was described as a 'Little chap with a round face and smokes a pipe. Looks like Harold Wilson' (Martin, 1979:126). Birtwistle was a student in Manchester, there he discovered Rookmaaker's thesis, he describes it as 'the greatest single influence in turning me away from irrationalism' although his first impression 'was that his tastes and interests were diametrically opposed to mine' (Martin, 1979:127). Birtwistle visited L'Abri in 1966 where he met Rookmaaker.

Birtwistle went on to study at the VU under Rookmaaker. From there he went on to the post of Assistant Professor in the Art History Department (Martin, 1979:129).

$25 \quad$ Walford was Professor of Art History at Wheaton College, Illinois, 1981-2011. He published some important works in the area of art history, see for example Walford (1991; 2001) and his website: http:// www.johnwalford.com/

26 The Inter-Varsity Fellowship (IVF) formed in 1928 became the Universities and College Christian Fellowship (UCCF) in 1974. It functioned as a para-church organisation supporting the Christian Unions (CUs) in universities and colleges across Britain. The history of the IVF/ UCCF is told in Coggan (1934) and Johnson (1979).

27 A Travelling Secretary or 'Trav Secs' as they were known, were itinerant UCCF workers, who visited university and college CUs offering encouragement and support. 
E. John Walford in 1969 wrote to Rookmaaker regarding a Dutch painting he had bought. Rookmaaker who was visiting London went to visit him (Martin, 1979:135). That was the start of a friendship. Walford then went to a conference at Ashburnham the following September where Rookmaaker was speaking (Martin, 1979:136). When Rookmaaker next visited the UK in October, Walford drove a minicab for him and his students. Rookmaaker then invited Walford to come to Amsterdam to study with him.

Rookmaaker's visits to Britain started in 1967 (Williams, 1987:28-37; Porter, 1993:103-120). He had contacted David Hanson in 1966 when Hanson was in London and asked him to find some art students for him to talk to (Gasque, 2003).

He was, in consequence, invited by members of Birmingham College of Art to come and speak to them. Among the members was Peter S. Smith. ${ }^{28}$ The UCCF Travelling Secretary, Meryl Doney (then Fergus) was warned by Oliver Barclay of Rookmaaker's Dooyeweerdian approach (Martin, 1979:142-143).

Arthur Pont and Peter Seccombe preceded Meryl Doney (née Fergus) who was succeeded by Tony Wales as Travelling Secretaries with responsibility for the Arts colleges. ${ }^{29}$ Meryl Fergus/ Doney was responsible for Rookmaaker while he was in the UK in 1967. Another who had responsibility in driving Rookmaaker during his stay in the UK was Ferghas MacFhionnlaigh.

Ferghas MacFhionnlaigh was a young and shy UCCF travelling secretary (1972-1975) in Scotland at the time. He recalls:

'As a travelling secretary I in fact had the honour of chauffeuring Hans Rookmaaker around Scotland one very snowy winter week on a University lecture tour. Unfortunately I was too young, too introvert (and too mentally inchoate) to ask him the many questions which come to mind now. I remember one piece of advice from him: 'Don't touch the windscreen - let the blower do it'. Actually, I do also recall the two of us sitting alone together in a dull empty Stirling University refectory one dark evening, with a couple of sad salads in front of us. In a randomly coherent moment, I ventured that verse in Revelation: "Their works shall follow them'. Did he think that somehow art would 'make it to heaven'? He chewed his ham and lettuce for a long time before answering. 'Yes'. Them were the days' (MacFhionnlaigh, personal communication November 2014).

28

Peter Smith was West Midlands Arts' Fine Arts Fellow 1977-9 and then head of Art at Kingston College of Further Education. He now has a studio in London.

Doney went on to become one of the editors of Third Way magazine. Tony Wales wrote an obituary of Rookmaaker in Third Way (Wales, 1977).
Ferghas who blogs at http://gobha-uisge.blogspot.co.uk/, often in Gaelic, is now a retired secondary art teacher in Inverness. He worked as a travelling secretary from 1971-1974 visiting and encouraging Scottish college Christian Unions for UCCF. His predecessor Don MacAulay used to lend him Presbyterian \& Reformed books including Dooyeweerd's Twilight and several of van Til and Rushdoony:

'Twilight's reference to an 'Apollos/ Dionysus' cultural disjunction remained with me and I talked to people enthusiastically about it. I saw the obvious connection with the Neo-Classical and Romantic art movements' (MacFhionnlaigh, personal communication November 2014).

Rookmaaker came to the UK in 1967 and delivered a talk to the Birmingham Art students 'Three steps to modern art'. He stayed up discussing art and art theory with the students until the early hours. The next day he was in London to lecture at the National Club. Rookmaaker came to the UK again in 1968 to speak to a number of art colleges (Barclay, 1997:90). He also spoke at a conference in Keele on 'Vocation' in 1968. It was in part due to this that the Arts Centre Group was born (Porter 1993). It was also during this time that he went to speak at a conference at Ashburnham with Francis Schaeffer. Richard and Janice Russell were present on that occasion.

Barclay, commenting on Rookmaaker and Schaeffer's influence, wrote 'Almost certainly the evangelical world of the 1930 s would have been negative about this decision, and a number still had doubts. There was now however, an openness and an attempt to think biblically about everything that could be seen as a God-given gift' (Barclay, 1997:91).

In 1971-72 Rookmaaker spoke over the New Year at the UCCF Graduate Fellowship's Annual Study Conference. The conference was on 'A Christian perspective on culture'. Rookmaaker gave three lectures on 'Beat, rock and protest', 'Creativity' and 'The arts today'. The conference was hosted by Donald and Mrs MacKay (Christian Graduate 1972 (Sept), 96). Rookmaaker's book was later positively reviewed in Christian Graduate by Rosamund Andrew. She mentions his 'Dutch Calvinist tradition which fosters a concern for the quality of life in society as a whole' (Andrew, 1971:78). The ACG grew from a Reformational root, but not all involved embraced the Dooyeweerdian perspective. Another group that has Reformational beginnings was the Ilkley Group. But not all Ilkley group members were sympathetic to a Dooyeweerdian approach.

\section{THE ILKLEY GROUP}

The Ilkley group was the initiative of David Lyon, who at the time was lecturing in sociology at Ilkley College. It was formed in 1971. One of the founder members was Elaine Storkey. The group also initially included Tony Walter, Tony Garood, Rob Furbey, Philip and Miriam Sampson and Alan Storkey. Richard Russell was also at one time a member of the group. His (1980) paper in A Reader in Sociology grew out of that group. 
The Ilkley group was 'a loose association of Christians who are concerned to investigate the relationships between Christian faith and sociology'. The first meeting was one weekend in Ilkley - hence the name of the group (Terpstra, 1983:11).

The group held weekend study sessions, at first twice a year and later once a year. A topic would be decided on and then papers prepared and discussed at the meetings. The first group publication was Christian Commitment and the Study of Sociology (1975) and in 1979 they contributed to an issue of Faith and Thought 106(2-3) on the topic of 'Ideology and idolatry'. The contributors for the latter included: Tony Walter (1979a, b, c), Howard Davis (1979), David Lyon (1979a, b), Alan Storkey (1979a), and the Sampsons (Sampson \& Sampson, 1979).

In 2000 the group comprised Keith White, Greg Smith, David Morgan, Elaine Storkey, Philip Sampson and Tony Garood.

\section{JOHN PECK AND COLLEGE HOUSE}

It was Hebden Taylor's The Christian Philosophy of Law, Politics, and the State (1966) that was instrumental in John Peck coming to a Reformational perspective. Peck is the co-founder of College House in Cambridge, co-founder of the Greenbelt festival, an author (Peck, 1979; 1989; Peck \& Strohmer, 2001) and Baptist minister at Earl Soham, Woodbridge, Surrey. He has also been a senior lecturer at the Bible Training Institute in Glasgow.

Converted in 1942 (Peck, 1989) he was brought up as a Christian with a strong world-separation mentality. This gave him a strong sacred/secular, grace/nature perspective which radically changed when he read Hebden Taylor: 'That book introduced me to the modal theory, and that theory unlocked so many of doors that enabled me to see the validity of the 'secular' areas of life' (Strohmer, 1998).

Peck goes on:

'Another key was that I began to understand that life was no longer divided into two unrelated bits, the religious and the secular. This revolutionized my understanding of spirituality. I saw quite clearly that spirituality is about obedience to God's order for the universe that we live in, and that God is just as involved in economics, or politics, or science, or art as $\mathrm{He}$ is in our church-related (religious) activities. The thing is, once you realize that these 'secular' laws are ordained by God then you're obeying God in obeying them' (Strohmer, 1998).

Peck moved from Glasgow in 1978 to take up the post of pastor of a Baptist church in Earl Soham, Suffolk. It was from there that the Koinonia School of Christian Practice (later to become College House) and the Greenbelt Arts Festival developed. The old rectory at Earl Soham had been bought four years before by Steve Shaw and James Holloway (a philosopher-bricklayer and member of the Fat Band) at auction at a price they couldn't afford! (Shaw, 1982). Shaw writes:
'We had a vague plan of starting some kind of study centre at the rectory where enlightened evangelicals could come down and, sitting around a good old log fire, do some intelligent Christian thinking about how to transform the world' (1982:14).

They persuaded Peck - Holloway's brother-in-law - and his family to move: College House was born. 'The aim was to teach Christians not so much to be pastors or missionaries like other Bible schools in England, but to do their everyday work and thinking about the world Christianly' (Shaw, 1982).

The first Greenbelt Festival was organised by members of the College House community. It took place on August Bank Holiday 1974 at Prospect farm, a pig farm near Woodbridge, in Suffolk. From 1975-1981 it was held in the grounds of Odell Castle in Bedfordshire. Those involved at the early stages included James Holloway, Steve Shaw and Jim Palosaari (1939-2011); it was initially financially sponsored by Kenneth Frampton's Deo Gloria Trust. Greenbelt is the largest Christian arts festival in the world. It is centred in the Christian faith but unbounded in that any are welcomed irrespective of their faith. Speakers and performers have included Bishops and Archbishops, Cliff Richard, Graham Kendrick, Adrian Snell, Parchment and Larry Norman as well as Calvin Seerveld, Caesar Molebatsi, Bruce Kent, John Selwyn Gummer, Jim Wallis, Anita Roddick, Billy Bragg, Tom Wright and Bruce Cockburn. Peck's vision for Greenbelt was that it should help people see 'every area of life as moulded by the Gospel.' At the first Greenbelt (GBo1) Peck spoke on the 'Westernisation of Christianity'. For GBo3, he brought a daily Bible reading 'Openhearted Living' and at GBO4 he looked at art and pornography (Northrup, 2003).

College House was a L'Abri-like project aimed at 'developing a Christian approach to life, the universe and everything. It had arisen out of needing to try to make sense out of Greenbelt, because the festival had become aware that it wasn't just about Art, but Life' (Peck \& Shaw 1990:10).

In 1982 Koinonia moved to Cambridge and became College House in Cambridge ( $\mathrm{CHiC}$ ). Also involved at the time were Steve Shaw as a part-time theologian and Carol Holliday as administrator. Steve Shaw had just returned from the ICS in Toronto. He went there in 1979 and completed an MPhil on John Hick. John Peck used to travel down from Earl Sotham to Cambridge when required. Others involved with College House around the time were Jonathan Chaplin c.1984 and Jeremy Ive c.1984 until c.1989 when he went for ordination training at Wycliffe Hall, Oxford. CHiC held two 12-week courses, the foundation course 'Faith to be human' and taking it further with 'Developing a Christian Philosophical Framework'. As well as many other weekend courses.

These included:

1986: 'No Splits: Journey to Human Wholeness' - with Steve Shaw, Viv Faull, Kathy Keay, Tony Walters, John Peck. Shaw weote a book with that title (Shaw, 1989). 
1987: 'Mirror, Mirror on the wall, why am I still so depressed?' with Carole Rich and Martin Evans

‘Creation Regained' - with John Peck and Steve Shaw

'From a Garden to a City - a Christian view of ecology, landscape and architecture' - with Tim Cooper and Tony Walter

1988: 'Rainbows for the fallen world' with Calvin Seerveld

1989: Summer Conference 21-23 July 'Christ and Culture' with Bishop Lesslie Newbigin, Eleanor Kreider, Michael Schluter, John Peck and Richard Russell.

In 1990 there were two key changes. They were awarded the franchise to teach the Cambridge Diploma in Religious Studies (Peck \& Shaw, 1990). However, soon afterwards the Shaws had a child and Shaw became a stay-at-home dad with little time to give to College House.

In 1986 The Open Christian College, which was loosely associated with College House, was initiated by Alan Storkey. It published a worldview course Introduction to a Christian Worldview. It was edited by Jonathan Chaplin and involved John Peck, Steve Shaw and Alan Storkey. Elaine Storkey prepared the accompanying cassette tape. The course was based on two key books Al Wolters' Creation Regained and Walsh and Middleton's Transforming Vision. The production team included Paul and Ruth Edwards, Ann Holt (who went on to work for CiE), Mary Mansfield and Wendy Shutt. Eventually, the OCC administration moved from Cambridge to Bath. The Bath committee members included Revd Richard Russell, Mark and Anne Roques, Paul Tuvey, Steve Bishop and Jim Tickner. In production at the time were two other courses, one on ecology (Tim Cooper) and the other on art (Adrienne Chaplin). They were never published; in part for financial reasons, but also because of the disappointing take-up of the Worldview course.

\section{THE ICS CONNECTION}

A number of Senior Members (i.e. professors) of the Institute for Christian Studies (ICS) that had their origins in the UK were Paul Marshall (from 1980), Jonathan Chaplin and Nik Ansell. Several Britishers were also junior members (students). These included Mark Roques, Pete Core and Nik Ansell from Bristol and David Woods (Cambridge), Nigel Douglas (Manchester), Steve Shaw (Suffolk and Cambridge) and David I. Smith (Derby).

A number of Britishers also lectured at the ICS: Tony Cramp (in 1974, 1978 and 1983), David Lyon (in 1977 and 1978), John Peck (in 1983 and 1986) and Alan Storkey (in 1981 and 1984).

Tony Cramp was a lecturer in economics and a fellow of Emmanuel College, Cambridge. He led a one-week seminar in 1983 on 'Economics in Christian Perspective: a sketch map' and for several years taught a Cambridge University course called 'A Christian Critique of Western Economic Theory'.

Others from Bristol went on to study under Bran Walsh: Paul Tuvey, Jon and Helen Jelfs and James Tickner. These were introduced to the ICS by the returning Mark Roques and his wife Anne Burghgraeff-Roques. Jelfs and Tuvey had been part of a church known as Bristol Christian Fellowship, a number of members of which were introduced to Reformational thought when Mark Roques returned from Toronto in 1987. They formed strong links with Richard Russell's CSU, then in Bath. A small number also started on the OCC Worldview course with Richard Russell and Mark Roques as their tutors.

At the time Bristol Christian Fellowship (BCF) ran a Christian school, Oak Hill School. It had recently started a senior department (aged 11+) and a number of staff, particularly in the senior department, were keen to develop education along Dooyeweerdian lines. This led to Arthur Jones, recently returned from Nepal and living at the time in Bolton, becoming the head of the senior school. However, there were soon conflicts with the eldership of BCF over the nature and control of the school. The issue of sphere sovereignty was not resolved. The school eventually 'separated' from BCF, but had to close soon after because of lack of finance. The principal Ruth Deakin was involved with a political campaign (Christian Schools Campaign) to gain public funding for Christian schools, but seemingly without much effect (Deakin, 1990a). Another Oak Hill school initiative was Bridgehead for Education (1990-1994) - a monthly weekend training session for Christian teachers (Bishop, 1991). The course leader was Ruth Deakin and main lecturers included Richard Russell, Mark Roques and Steve Bishop and several guest lecturers, including Arthur Jones, Elmer Thiessen, Trevor Cooling, Ann Holt and Roger Slack.

Oak Hill School was affiliated to the Christian Schools' Trust (CST) (Deakin, 1990b). A science curriculum working group was set up under the auspices of the CST. The chair was Roger Slack and Arthur Jones the convenor. A number of publications were produced by the group (see for example Bishop 1992; Bishop and Carpenter, 1993, 1995; Jones, 1998) all written from a Dooyeweerdian perspective.

\section{WYSOCS}

WYSOCS - the West Yorkshire School of Christian Studies was formed at a suggestion of the Anglican evangelical John R.W. Stott (1921-2011) by David Lyon and Ruth Hanson in 1989. Its initial model was the London Institute for Contemporary, Christianity (LICC - see below) which had been founded by Stott in 1982. WYSOCS has always had it base in Leeds.

The charitable commission aims are given as:

WYSOCS gives opportunity for learning in many subjects and on many issues from a Christian perspective. We offer lectures, conferences and study courses for adult students and employ a researcher to develop effective teaching materials for use by Christian youth organisations. We can harness the best in Christian scholarship through our international academic network for educational purposes.

The years up to 2000 saw lectures and conferences on a wide range 
of topics from Developing a Christian mind (1986, with lectures from Nick Isbister, Steve Walton, Michael Schluter, Elaine Storkey, David Lyon and Roy McCloughry), Routes in history 1987, with Richard Russell, David Hanson, Ron Elsdon, John Wolfe, Elaine Storkey, Geraint Fielder, Kathy Keay, R. Tudor Jones and Elaine and Alan Kreider), Christian philosophy, Islamic Britain, Worldviews in the classroom, homosexuality, Psychology, Preaching, Callings, the Far-eastern mind, genetics, development ...

In 1986 there was a joint conference with LICC called Salt and Light. International speakers at WYSOCS included Harry van Dyke in 1991 speaking on Revolution and history; Bob Goudzwaard on Economics and aspects and visions (1995); Calvin Seerveld in 1995 on 'How to see and teach about worldviews in painting and sculpture. 1996 saw an involvement with Lesslie Newbigin of The Gospel and Culture network. Newbigin was impressed with the Kuyperian vision and engaged in conversation at WYSOCS with Mike Goheen, Roy Clouser, Danie Strauss, Jim Skillen, Al Wolters, Gene Haas, Harry Van Dyke and George Vandervelde at a specially organised conference on 'Christian Society ${ }^{30}$ Witnessing to the Gospel of the Kingdom in the Public Life of Western Culture.' Newbigin's closing remarks at the 1996 conference were:

“"the Gospel and Our Culture network has hardly begun to answer the questions of mission in the public square" and that the "Reformational, Kuyperian tradition has obviously been at work long ago spelling out concretely in the various spheres of society what it means to say "Jesus is Lord."' He continued, "unfortunately this Kuyperian tradition is almost unknown in Britain" and expressed his fervent wish that it "would become a powerful voice in the life of British Christianity' (Goheen, 1997:8)

There was a follow-up three-day consultation in June 1997 on 'The Church's Mission in Public Life' with Goheen, Hanson, Richard Middleton, Strauss, Goudzwaard, Skillen, Harry Fernhout and Lesslie Newbigin (Contact, 1997). Unfortunately, Newbigin's death in 1998 ended the dialogue.

From WYSOCS developed Reality Bites, Life Matters and FiSCH (Faith in Scholarship). Arthur Jones and Mark Roques were employed on a part-time basis and developed initiatives such as a gap year (which ran from 2002-2006) and resources for school workers.

\section{THE STORKEYS, THE SHAFTESBURY PROJECT AND LICC}

The Shaftesbury Education and Research Trust as it was originally called became the Shaftesbury Project on Christian Involvement in Society. It was set up in response to a 1967 article in the Church of England Newspaper by Richard Allen who had floated the idea of an evangelical research institution. The first full-time director, appointed in 1969, was Alan Storkey. Roots of Western Culture - Newbigin in return sent back a four-page response.
Storkey (b 1943) was married to Elaine (née Lively) in 1968 by Hebden Taylor (see above). At the time Storkey held his first academic post at the University of Sterling (1968-1969). The Storkeys then moved to the Nottingham area, when Alan became the Director of the Shaftesbury Project. He later taught economics and politics at Worksop College. In 1979 IVP published Alan's A Christian Social Perspective. This is an uncompromisingly Dooyeweerdian approach to sociology. What is most surprising is that it was published by IVP, the publishing arm of the UCCF. UCCF - under the influence of Oliver Barclay - was very resistant to Dooyeweerdian ideas.

Storkey's book started as a course of lectures at Bedford College sponsored by London Bible College. The 1976 CSU summer conference was also a place for Storkey to try out some of the ideas in the book. He acknowledges the 'anarchic body' of the Christian Studies Unit in the preface as well as Pat Dearnley and those he worked with on the Shaftesbury project, and Andrew Brockett, Sir Fred Catherwood, David Lyon, Tony Cramp, Fred Jones and Richard Russell for reading parts or whole of the book (Storkey, 1979:12).

During the 1980-81 academic year the Storkeys were visiting professors in sociology at Calvin College. After the return from the States Alan Storkey took up a post of Director of Studies at Oak Hill College, a post he held for 20 years until 2003.Under Storkey, the Shaftesbury project had a Kuyperian approach, but this was diluted after Storkey left under the succeeding directorships of Pat Dearnley and John Gladwin.

Elaine Storkey became the executive director of the London Institute for Contemporary Christianity (LICC), which was originally set up by John R.W. Stott in 1982. Stott's 'core belief' according to the LICC websites was' that every part of our lives comes under the Lordship of Christ, and that all of life is a context for worship, mission, ministry and active Christian engagement. ${ }^{31} \mathrm{~A}$ vision sounding remarkably Kuyperian. However, Stott in his extensive writings only mentioned Kuyper once (Stott, 1992:97). LICC had begun in April 1982 under the auspices of John Stott (Chapman, 2012:103). It began with a ten-week course with 27 students (Dudley-Smith, 2001:285). The development of LICC had taken seven years. In 1979 Stott had held meetings with John Gladwin, then the Director of the Shaftesbury project, Andrew Kirk, Oliver Barclay and Os Guinness. Part of the inspiration for LICC had come from Regent College in Vancouver (Dudley-Smith, 2001:288). Stott had met James Houston, the first principal of regent, in 1971 and in 1974 when they both visited Francis Schaeffer. Stott was the Director for the first 5 years. Then Martyn Eden became Dean, and Ernest Lucas the Director of Studies, Stott became the President. Although the LICC was keen to promote a Christian mind, it was never fully Reformational in its approach. Elaine Storkey was the director of LICC from 1992 until 1999, before that she was a lecturer at Oak Hill (1983-1987) and at the Open University (1987-1992).

31 http://www.licc.org.uk/about-licc. Date accessed 12 December 2015. 
LICC and the Shaftesbury Project both suffering financial difficulties united in 1988 to become Christian Impact. ${ }^{32}$

\section{THE TWENTY-FIRST CENTURY}

I have mainly looked at most of the events in England up until 2000. The story beyond then needs to be told; this may be the subject of a subsequent paper in a few years' time! The key events are the development of WYSOCS into three brands: Life Matters, Reality Bites and FiSCH, and then a name change to Thinking Faith Network. The www.allofliferedeemed.co.uk website was launched in 2005. Two important Reformational colloquia took place: the first in 2006 at WYSOCS 'headquarters' - the second also at Leeds but this time at Trinity University in July 2012 with a theme of education. After the 2006 colloquium a Reformational UK blog was launched by Rudi Hayward with editorial support from Geoff Hall, Steve Bishop and Simon Kay.

Jonathan and Adrienne Chaplin returned to the UK where Jonathan took up a post as KLICE head and as part of that organised the Dooyeweerd Research Seminar conference at Tyndale House, Cambridge on $6^{\text {th }}$ February 2010. Delivering the main papers were Jonathan Chaplin, David McIlroy, Jeremy Ive, Andrew Basden and Arthur Jones. Respondents included Henk Geertsema and Rudi Hayward.

Peter Heslam after completing a $\mathrm{PhD}$ at Oxford in 1993 on Kuyper (Heslam, 1998) set up Transforming Business and Jeremy Ive completed a PhD from King's College, London, on Dooyeweerd and Vollenhoven (2005-2012). Jeremy Begbie who completed a PhD at Aberdeen on "Theology, Ontology and the Philosophy of Art, with Special Reference to Paul Tillich and the Dutch NeoCalvinists' (see also Begbie, 1991), went on to develop a theology of the arts and in 2000 founded The Institute for Theology, Imagination and the Arts at St. Andrews University, Scotland. Also of major significance is Andrew Basden's work in applying Dooyeweerdian ideas to information systems at Salford University. Basden has been extremely successful in alerting non-Christian academics to Dooyeweerd's approach (Basden, 2008) in recognition of his work he was given a special chair at Salford University: the Chair of Human Factors and Philosophy of Information Systems. ${ }^{33}$ Basden's ever-expanding Dooyeweerd pages (http://kgsvr.net/dooy/) began in 1997 and provide open access to much of Dooyeweerd's thinking.

The future of Reformational philosophy in the UK may not be very bright, but there are small flickers of activity around the country. The challenge is to make the Reformational approach accessible and engaging to a younger generation. Many Christians are waking up to the need for a 'public theology' and are becoming aware that a dualistic and pietistic Christianity is failing to provide a framework for engagement. While Reformational scholars may not be happy with the phrase 'public theology', not least because it hints at prioritising

32 The name Christian Impact never really took off and in 1997 the organisation became known as LICC again at Spring Harvest (Basden, 2011). theology, it may provide a way in to show the fruitfulness and integrated nature of a Reformational worldview.

\section{ACKNOWLEDGEMENTS}

I would like to express my thanks to Rex Ambler, Jonathan Chaplin, Antoni Diller, Tony Garood, David Hanson, Irving Hexham, Arthur Jones, Ferghas MacFhionnlaigh, Duncan Roper, Richard Russell, Steve Shaw, Alan \& Elaine Storkey and Colin Wright for sharing their memories and in some cases books and papers with me. 


\section{BIBLIOGRAPHY}

Ambler, R. 1967. 'The Christian mind of Abraham Kuyper', In Profitable for Doctrine and Reproof. London: Puritan and Reformed Studies Conference.

Ambler, R. 2013. Quaker Way: A Rediscovery. Alresford: Christian Alternative Books.

Andrew, R. 1971. 'Review of Modern Art and the death of a culture', Christian Graduate XXIV(3):77-79.

Barclay, O. 1997. Evangelicalism in Britain 1935-1995: A Personal Sketch. Leicester: IVP.

Basden, A. 2008. Philosophical Frameworks for Understanding Information Systems. Hersey, PA: IGI Publishing.

Basden, A. 2011. The story of the Dooyeweerd pages'. http://kgsvr.net/dooy/story. html Date accessed 1 March 2016.

Beckwith, R. 1990. 'In Memoriam: Dr. Philip Edgcumbe Hughes', The Churchman 104(4):351-352.

Begbie, J. 1991. Voicing Creation's Praise: Towards a Theology of the Arts. Edinburgh: T \& T Clark.

Bishop, S. 1991. 'Bridgehead for Education', ACT Now 24:26-27.

Bishop, S. 1992, 'Constructivism', Christians in Science, Education Newsletter 3:8-10.

Bishop, S. 2016a. 'A History of the Reformational Movement in Britain: The PreWorld War II Years', Koers, accepted for publication.

Bishop, S. 2016b - change in title and now published. 'A Tribute to E.L. Hebden Taylor (1925-2006): A British Export to North America', Pro Rege 44(4):3-10.

Bishop, S. \& Carpenter, J. 1993. 'Constructivism', Spectrum 25(2):147-158.

Bishop, S. \& Carpenter, J. 1995, 'Process science?', Spectrum 27(1):59-71.

Bishop, S \& Kok, J. (Ed.) 2013. On Kuyper: A Collection of Readings on the Life, Work \& Legacy of Abraham Kuyper. Sioux Center, lowa: Dordt College Press.

Brown, C. 1967. 'Review', Churchman 81(2):131-132.

Brown, C. 1969. Philosophy and the Christian Faith. Leicester: Inter-Varsity press.

Brown, C. 2009. The Death of Christian Britain: Understanding Secularisation 1800-2000 ( $2^{\text {nd }}$ edn), Oxford: Routledge.

Chapman, A. 2012. Godly Ambition. John Stott and the Evangelical Movement. Oxford: Oxford University Press.

Coletto, R. 2010. 'Traces of neo-Calvinism in France and Italy', Koers 75(1):149-172.

Coggan, F.D. (ed.) 1934. Christ and the Colleges: A History of the Inter-varsity Fellowship of Evangelical Unions. London: IVF.

Contact 1997. 'WYSOCS Conference: Conversations with Lesslie Newbigin', Contact 9(1).

Davis, H.H.1979. 'Homeless Minds?' Faith and Thought 106(2/3):96-109.

Deakin, R. 1989a. The New Christian Schools: The Case for Public Funding. Bristol: Regius Press.

Deakin, R. 1989b. The New Christian Schools. Bristol: Regius Press.

De Gaay Fortman, W.F., Hommes, H.J., Dengerink, J.D., Langemeijer, G.E., Mekkers, J.P.A., Van Peursen, C.A., Stellingwerff, J. 1965, Philosophy and Christianity: Philosophical Essays Dedicated to Professor Dr. Herman Dooyeweerd. Kampen: J. H. Kok.
Dengerink, J.D. 1954, “"The Christian student and general culture” Address at an IFES conference', Christian Graduate 7(1).

Dengerink, J.D. 1962a. 'Cambridge 1961', International Reformed Bulletin 8:3-6.

Dengerink, J.D. 1962b. 'Editorial', International Reformed Bulletin 11 (October):1.

Dengerink, J.D. 1963. 'I.A.R.F.A. 1953-1963', International Reformed Bulletin 14 (July):5-8.

Dooyeweerd, H. 1947. Introduction to a transcendental criticism oaf philosophic thought. Evangelical Quarterly XIX(1):41-51.

Dooyeweerd, H. 1948a, Introduction à une critique transcendentale de la pensée philosophique. (In Mélanges philosophiques. Bibliothèque du X Congrés International de Philosophie. Vol. 2. Amsterdam: Veen S.A. p. 70-82.

Dooyeweerd, H. 1948b. Transcendental Problems of Philosophic Thought: An Inquiry into the Transcendental Conditions of Philosophy. Grand Rapids: Eerdmans.

Dooyeweerd, H.1954. 'La sécularisation de la science'. La Revue Réformée 5:138-157.

Dooyeweerd, H. 1960. In the Twilight of Western Thought. Nutley, NJ: Craig Press.

Dooyeweerd, H. 1966. The secularisation of science', International Reformed Bulletin 26(July):2-17.

Duffield, G.E. 1964. 'New evangelical impetus in England', International Reformed Bulletin 19 (October):12-16.

Dudley-Smith, T. 2001. John Stott: A Global Ministry. Inter-Varsity Press, Leicester.

The Editor [Burleigh J.H.S.] 1949. 'Dutch theological scholarship', Evangelical Quarterly XXI (1):71-72.

Gasque, L. 2003. Hans Rookmaaker: An Open Life. In The Complete Works of H.R. Rookmaaker, Part 4, Volume 6. Carlisle: Piquant.

Goheen, M. 1999. 'Mission and The Public Life of Western Culture: The Kuyperian Tradition'. The Gospel and Our Culture (U.K.) 26 (Autumn):6-8.

Haas, J.W. Jr. 1992. 'Donald MacCrimmon MacKay (1922-1987): A View from the Other Side of the Atlantic', Perspectives on Science and Christian Faith 44:55-61.

Hanson, D. 2006, 'How the Reformational Movement got started in the UK', Paper presented at the 2006 UK Reformational Colloquium, Leeds.

Harinck, G. (Ed.) 2012. Kuyper in America. Sioux Center, lowa: Dordt College Press.

Hebden Taylor, E.L. 1960. 'Four years inside a Yukon dog collar', Queen's Quarterly 66 (Winter):664-676

Hebden Taylor, E.L. 1962. Why work? The Christian Answer: A Case for Christian Labour Unions. Rexdale, Ont.: Christian Labour Association of Canada.

Hebden Taylor, E.L. 1964. 'Christ's kingship over British culture'. International Reformed Bulletin 19 (October):16-21.

Hebden Taylor, E.L. 1966. Christian Philosophy of the Law, Politics and the State. A Study of the Political and Legal Thought of Herman Dooyeweerd of the Free University of Amsterdam, Holland as the Basis for Christian Action in the English-Speaking World. Nutley, NJ: Craig Press.

Hebden Taylor, E.L. 1970. Reformation or Revolution. Nutley, NJ: The Craig Press.

Hebden Taylor, E.L. 1972. 'Preface to the second edition', (In Van Til, H. The Calvinistic Concept of Culture. Philadelphia, Presbyterian \& Reformed. p. 9).

Hirst, R.J. 1949. 'Review of Transcendental Problems of Philosophic Thought by Herman Dooyeweerd' Mind 58:406. 
Heslam P.S. 2013, 'Theology of the Arts: Kuyper's Ideas on Art and Religion' (In Bishop, S. \& Kok, J. (ed.), On Kuyper. Sioux Center, IA: Dordt College Press. p. 351-364).

Heslam, P.S. 1998. Creating a Christian Worldview: Abraham Kuyper's Lectures on Calvinism. Carlisle: Paternoster Press.

Hexham, I. 1970. A New Tendency towards Christian Reformed Philosophy in England. Bulletin van die Suid-Afrikaanse Vereniging vir die bevordering van Christelike Weyenskap 22:39-43.

Hexham, I. 1971. Perspective Newsletter August 20, 1971.

Hexham, I. 1972a. 'Report on IVF and CSU Winter Conferences in Britain', Perspective Newsletter 6(2):16-17

Hexham, I. 1972b. 'Some Aspects of the Contemporary Search for an Alternative Society', MA thesis, University of Bristol.

Hexham, I. 1975. 'Totalitarian Calvinism: The Reformed "Dopper" Community in South Africa, 1902-1919', PhD dissertation, University of Bristol.

Hexham, I. 1981. The Irony of Apartheid. Lewiston: Edwin Mellen.

Hoogstra, J.T. (ed.) 1939. The Sovereignty of God: The Proceedings of the First American Calvinistic Conference. Grand Rapids: Zondervan.

Hoogstra, J.T. 1957. International Calvinism. American Calvinism: A Survey. Grand Rapids: Baker Book House.

Hughes, P.E. 1966. Creative Minds in Contemporary Theology. Grand Rapids: Eerdmans.

Johnson, D. 1979. Contending for the Faith: A History of the Evangelical Movement in the Universities and Colleges. Leicester: IVP.

Jones, A. (ed.) 1998. Science in Faith: A Christian Perspective on Teaching Science. Romford: Christian Schools' Trust.

Keddie, G.J. 1970. 'Association for the Advancement of Christian Scholarship', Banner of Truth Magazine 85:11-12.

Leegewater, A. 1996. 'Reijer Hooykaas (1906-1994): A Modern Advocate for Philosophia Libera', Perspectives on Science and Christian Faith 48:98-103.

Lloyd-Jones, D.M. 1976. 'The French Revolution and after', In The Christian and the State in Revolutionary Times. Westminster Conference Papers, pp. 94-110.

Lloyd-Jones, D.M. 1981. 'The Living God', The Evangelical Magazine of Wales (April).

Lyon, D. 1979a. 'Progress, Manipulation, and the Welfare State,' Faith and Thought 106(2/3):110-121.

Lyon, D. 1979b. 'Idolatry and the Prophetic Task', Faith and Thought 106 $(2 / 3): 195-201$.

Marcel. P. 2013a. The Christian Philosophy of Herman Dooyeweerd. I. The Transcendental Critique of Theoretical Thought. Aalten: Wordbridge.

Marcel. P. 2013b. The Christian Philosophy of Herman Dooyeweerd. II. The General Theory of the Law-Spheres. Aalten: Wordbridge.

Martin, L. 1979. Hans Rookmaaker: A Biography. London: Hodder \& Stoughton.

Northrup, P. 2003. Turning Thirty. London: Greenbelt Festivals.

O’Keefe, B. 1990. 'The case for public funding'. Third Way 13(2):8.

Otto, P. 2005. 'In the twilight of Dooyeweerd's corpus: The publishing history of in the twilight of western thought and the future of Dooyeweerd studies', Philosophia Reformata 70(1):23-40.
Packer, J.I. 1954. 'The Christian approach to culture', Christian Graduate VII(I):6-12.

Peck, J. 1989. Wisdom in the Marketplace. Greenbelt Festivals.

Peck, J. 1979. What the Bible Teaches about the Holy Spirit. Eastbourne: Kingsway.

Peck, J. \& Shaw, S. 1990. 'College House - back to schooldays', Third Way 13(9):10-11.

Peck, J. \& Strohmer, C. 2001. Uncommon Sense: God's Wisdom for our Complex and Changing World. London: SPCK.

Porter, D. 1993. Arts and Minds: The Story of Nigel Goodwin. London: Hodder \& Stoughton.

Price, R.M. 1988. Clark H. Pinnock: Conservative and Contemporary. Evangelical Quarterly 88(2):157-183.

Roennfeldt, R.C. 1990. Clark H. Pinnock's Shift in His Doctrine of Biblical Authority and Reliability, an Analysis and Critique. PhD Thesis, St. Andrews University.

Rookmaaker, H. 1970. Modern Art and the Death of a Culture. Leicester; IVP.

Rookmaaker, H. 1978. Art Needs no Justification. Leicester: IVP.

Russell, R.A.1967a. 'An examination of the relation of religious ground motives and philosophical analysis'. MA Dissertation.

Russell, R.A. 1967b. Philosophy and the Christian.

Russell, R.A.1973. 'The growing crisis of the evangelical worldview and its resolutions', MA Dissertation, Bristol University

Russell, R.A. 1976. 'Reason and Commitment in Education', MEd Bristol University.

Russell, R.A. 1980. 'Practical placement: academic year 1979-80', Trinity College, Bristol.

Russel, R.A. 1984. Christian Faith \& Public Religion', Third Way 7(8):10-13.

Russell R.A. 2006. 'Confessions of a book-pushing bearded ideologue', UK Reformational Colloquium, Leeds.

Rusthoven, J. 2014. Covenantal Biomedical Ethics for Contemporary Medicine: An Alternative to Principles-Based Ethics. Eugene, OR: Wipf and Stcok.

Sampson, P. \& Sampson, M. 1979. 'Necessity and Freedom,' Faith and Thought 106(2/3):151-168.

Shaw, S. 1982. 'How things reformational got started in England', Perspective 16(2):14-15.

Shaw, S. 1989. No Splits. Basingstoke: Marshall Pickering.

Simons, P. 2006, 'Reformational philosophy in New Zealand', online: http://www. allofliferedeemed.co.uk/personalperspectives.htm date accessed: 3 February 2016.

Steen, P. 1968. Review of Set Forth Your Case by C. Pinnock. Westminster Theological Journal 31(1):102-110.

Storkey, A. 1979a. 'Illusion and Substance - the Image in the Media,' Faith and Thought 106(2/3):122-134.

Storkey, A. 1979b. A Christian Social Perspective. Leicester: IVP.

Storkey, E. 2014. E-mail conversation August/ September 2014.

Stott, J. 1992. The Contemporary Christian: An Urgent Plea for double Listening. Leicester: IVP. 
Strohmer, C. 1998, 'John Peck (wisdom \& worldview) Interview', Openings (Autumn) 1:1. Online: http://www.charlesstrohmer.com/writings/interviews/ john-peck-wisdom-and-worldview/

Summers, D.F. 1962. 'Report Re: The Request of the Reverend E. L. H. Taylor to present the matter of the Christian Labour Association of Canada to the Ontario House of Bishops', Presented to Bishop H. R. Hunt of Toronto Diocese in June 1962.

Sutherland, S. 1969. Philosophy and The Christian - A Reply.

Tait, P. 1985. 'The Sovereign Grace Union', The Gospel Magazine May/ June. 102-105.

Terpstra, N. 1983. 'Wide angle lens: the renewal in sociology', Perspective 17(3):11

Thomas, G. 1968. 'The International Reformed congress: A report', Banner of Truth 60:31-34.

Van Til, H. 1972. The Calvinistic Concept of Culture. Philadelphia: Presbyterian \& Reformed.

Walford, J.E. 1991. Jacob van Ruisdael and the Perception of Landscape. New Haven: Yale University Press.

Walford, J.E. 2002. Great Themes in Art. Upper Saddle River: Prentice Hall.

Wales, T. 1977. 'H.R. Rookmaaker', Third Way 24 March, 10.

Walter, J.A. 1979a. 'Introduction: Idols and Ideologies,' Faith and Thought 106.2/3 (1979): 91-95.

Walter, J.A. 1979b. 'Salvation and Work: a Christian Critique of the Modern Ideology of Work, 'Faith and Thought 106(2/3): 135-150.

Walter, J.A. 1979c. 'Bad Kids and Bad Homes; Criminological Ideology, the Idolatry of the Modern Family,' Faith and Thought 106(2/3):169-177.

Welbourn, F.B. 1978. Atoms and Ancestors. Edward Arnold.

Williams, D. 1987. Not Once but Twice. London: Hodder \& Stoughton.

Young, W. 1966, 'Herman Dooyeweerd' (In Hughes, P.E. (ed.) Creative Minds in Contemporary Theology. Grand Rapids: Eerdmans. p. 270-305.) 